\title{
PENGARUH LATIHAN PULL OVER TERHADAP KEMAMPUAN SMASH PADA PERMAINAN BULUTANGKIS
}

\author{
Sudiadharma $^{1}$, Muhammad Ishak ${ }^{2}$
}

Keywords :

Exercise Pull Over;

Badminton Smash

Corespondensi Author

${ }^{1}$ Universitas Negeri Makassar, sudiadharma@unm.ac.id

${ }^{2}$ Universitas Negeri Makassar, m.ishak@unm.ac.id

Article History

Received: April

Reviewed: April

Accepted: Mei

Published: Juni

\begin{abstract}
This study aims to determine the effect of pull over training on smash ability in badminton games. This research is experimental. The population is UNM FIK students. The sample used was 20 people consisting of 10 people in each training group. The sampling technique is ordinal matching. The data analysis technique used was descriptive analysis, requirements test, and t-test at a significant level of $95 \%$ or 0.05 . The results showed that: (1) There was a significant effect of pull over training on smash ability in badminton games, with the value of $t$ count $=-11,000<$ from $t$ table $=1,833$ at a significant level of $95 \%$ or 0.05 . (2) There is an insignificant influence of the control group on smash ability in badminton games. The value of t count $=\quad-6,000<$ from $t$ table $=1,833$ at a significant level of $95 \%$ or 0.05 . (3) There is a difference in effect between pull over and control groups on smash ability in badminton games by obtaining t count $=3.674>$ from t table $=1.833$ and $P$ value $(0.546>$ 0.05)
\end{abstract}

\section{PENDAHULUAN}

Pengembangan dan pembinaan bulutangkis, seperti halnya dengan cabangcabang olahraga lainnya, ditentukan oleh berbagai faktor yang saling terkait. Di samping faktor atlet (olahragawan) itu sendiri, keberhasilan pengembangan dan pembinaan prestasi dipengaruhi pula oleh tersedianya pelatih yang baik, fasilitas dan alat yang baik dan bermutu, organisasi yang baik dan efektif, serta adanya suasana dan dorongan dari masyarakat dan pemerintah. Permainan bulutangkis merupakan permainan yang memiliki gerakan-gerakan yang dinamis serta memiliki kondisi fisik yang kompleks seperti kekuatan, kecepatan, kelincahan, daya tahan, power, reaksi, dan koordinasi, dimana seorang pemain dituntut harus dapat melakukan gerakan yang cepat seperti: melompat, berlari, melangkah arah depan belakang, serong kiri dan kanan. Permainan bulutangkis membutuhkan suatu kemampuan keterampilan khusus didalam bermain, seperti: cara memegang raket, sikap-posisi berdiri, jenisjenis pukulan dan kerja langkah kaki. Untuk dapat bermain bulutangkis dengan baik diperlukan penguasaan keterampilan gerak bulutangkis. Abraham Razak (1986), mengemukakan bahwa: "Keterampilan gerak bulutangkis adalah penguasaan teknik-teknik dasar pemain bulutangkis seperti pukulan lob, servis, dan smash". Salah satu teknik dasar yang ada pada permainan bulutangkis adalah pukulan smash. Pukulan smash merupakan andalan yang wajib dimiliki bagi setiap pemain, terutama dalam pertandingan, memenangkan 


\section{e-ISSN: 2657-0703 dan p-ISSN: 2085-5389}

pertandingan tersebut seorang pemain harus memiliki kemampuan pukulan smash yang baik. Peningkatkan kemampuan smash pada permainan bulutangkis, perlu memberikan bentuk latihan fisik beban untuk meningkatkan Performa kekuatan otot lengan untuk mendukung keberhasilan dalam melakukan pukulan smash. Komponen-komponen penting dalam otot adalah aktin dan miosin tertarik menjadi satu ikatan maka terjadi suatu kontraksi otot. Untuk meningkatkan kekuatan otot lengan, maka kemampuan otot lengan yang digunakan pada saat melakukan pukulan smash adalah pada aktivitas yang cepat. Untuk meningkatkan kemampuan pukulan smash pada permainan bulutangkis, maka kebiasaan kebiasaan yang sering dilakukan dengan teknik yang salah perlu diperbaiki. Salah satu yang harus diperhatikan adalah bagaimana pola gerak pada pukulan smash dan selain itu harus memperbanyak bentuk latihan fisik untuk meningkatkan performa. Kekuatan otot lengan untuk mendukung keberhasilan dalam melakukan pukulan smash. Untuk itu perlu dipilih bentuk latihan fisik yang cocok untuk meningkatkan kemampuan pukulan smash. Salah satu bentuk latihan baik, yaitu untuk meningkatkan kekuatan otot lengan. Sajoto (1995: 38) menyatakan bahwa: "kekuatan otot lengan adalah komponen kondisi fisik yang dapat ditingkatkan sampai batas sub maksimal sesuai dengan kebutuhan setiap cabang olahraga yang memerlukan". Latihan pull over merupakan latihan fisik untuk meningkatkan kemampuan kekuatan otot lengan bagian atas (biceps dan triceps), Sajoto (1988:99), mengatakan bahwa: "kekuatan otot adalah komponen kondisi fisik yang dapat ditingkatkan sampai batas sub maksimal, sesuai dengan kebutuhan setiap cabang olahraga yang memerlukan". Sejalan dengan pendapat tersebut, maka dapat dikatakan bahwa latihan pull over dapat meningkatkan kekuatan otot lengan dan akan memberikan pengaruh yang positif terhadap kemampuan pukulan smash.

Keterampilan adalah kesanggupan menggunakan pengetahuan seseorang secara evektif dan secara siap dalam pelaksanaan, serta mencapai kemantapan dari suatu keberhasilan dalam mencapai suatu tujuan. Sejalan dengan yang dikemukakan oleh Singer (1989:9), bahwa keterampilan adalah: "in the concistent degree of success is achieving on objective with efficiency and effective needs". Yang secara sederhana diartikan sebagai berikut: keterampilan adalah derajat kematangan atau kemantapan dari suatu keberhasilan dalam mencapai tujuan secara tepat guna dan efektif. Permainan bulutangkis merupakan permainan yang bersifat individual yang dapat dilakukan dengan satu orang melawan satu orang atau dua orang melawan dua orang. Permainan ini menggunakan raket sebagai alat pemukul shuttlecock sebagai obyek pukulan, lapangan permainan berbentuk segi empat dan dibatasi oleh net untuk memisahkan antara daerah permainan sendiri dan daerah permainan lawan. Tujuan permainan bulutangkis adalah berusaha untuk menjatuhkan shuttlecock di daerah permainan lawan dan berusaha agar lawan tidak dapat memukul shuttlecock dan menjatuhkannya di daerah permainan sendiri. Pada saat permainan berlangsung, masing-masing harus berusaha agar shuttlecock tidak menyentuh lantai di daerah permainan sendiri. Permainan bulutangkis adalah cabang olahraga permainan yang membutuhkan kecepatan, kekuatan, power dan daya tahan. Selain itu juga mempunyai keterampilan khusus yang harus dikuasai dengan tujuan untuk dapat mengembalikan bola dengan sebaik-baiknya. Untuk dapat bermain bulutangkis dengan baik serta mampu mempertahankan bentuk permainannya diperlukan latihan yang secara berulang-ulang, dan meningkatkan kesanggupan pemain secara efektif dan siap dalam pelaksanaan, serta mencapai kemantapan dari suatu keberhasilan dalam mencapai tujuan.

Pelaksanaan gerak adalah salah satu tuntutan di dalam bermain bulutangkis. Di dalam usaha gerak terampil yang kemudian membuat pertimbangan dalam menempatkan bola, selanjutnya mengambil keputusan untuk dapat melakukan pukulan atau serangan maupun yang terjadi sebaliknya, dengan memperhatikan faktor-faktor yang dimaksud adalah memperhatikan lawan bermaian (posisi) dan memperhatikan persiapan lawan pada waktu menanti bola disajikan. Hal yang perlu diperhatikan dalam melakukan pukulan smash atau pola gerak pukulan smash. PB. PBSI (2002:30), dijelaskan sebagai berikut: (1) Biasakan bergerak cepat untuk mengambil posisi memukul yang tepat, (2) Perhatikan pegangan raket, (3) Sikap badan harus tetap 


\section{Volume 10 Nomor 2 Juni 2018}

lentur, kedua lutut dibengkokkan dan tetap berkonsentrasi pada bola, (4) Perkenaan raket dan bola, diatas kepala dengan cara meluruskan lengan untuk menjangkau bola setinggi mungkin dan pergunakan tenaga pergelangan tangan pada saat memukul bola, dan (5) Akhiri rangkaian gerakan pukulan dengan gerak lanjut ayunan raket yang sempurna kedepan badan.

Pada dasarnya latihan pull over didesain untuk mengembangkan unsur fisik terutama pada kekuatan lengan dan bahu yang merupakan unsur penggerak utama dalam melakukan pukulan smash. Pelaksanaan gerakannya yaitu: Diawali dengan sikap berdiri, sambil memegang barbel dibelakang kepala dengan dua tangan, lalu kedua tangan diluruskan keatas sampai kedepan dada dengan cara mengangkat barbel sampai lengan lurus keatas. Menurut Harsono (1988:210), mengemukakan bahwa: "otot-otot yang terlatih pada gerakan pull over, terutama pada otot dada, latisimus dorsi, teres mayor pactoralis, rhomboids, triceps, coracobracialis, biceps bagian atas". Pelaksanaan latihan pull over dapat dianalisis sebagai berikut: (1) Posisi badan berdiri, (2) Pegang batang barbel dengan girp pronasi, (3) Kedua tangan berjarak lebih lebar dari bahu dan barbel dibelakang kepala kemudian didorong ke atas melewati kepala sampai ke depan dada, (4) Kembalikan kembali ke belakang kepala dan lakukan secara berulang-ulang serta bertahan sesuai dengan program latihan. Sasaran utama pemberian latihan pull over adalah untuk mengembangkan unsur power atau daya ledak pada lengan dan bahu sehinggah diharapkan setelah pemberian latihan pull over maka kekuatan dapat dikembangkan. Adapun latihan pull over di modifikasikan dengan sikap berdiri, dimana pelaksanaan latihan diawali dengan sikap berdiri, sambil memegang barbel dibelakang kepala dengan dua tangan, lalu kedua tangan diluruskan ke atas sampai ke depan dada dengan cara mengangkat barbel sampai lengan lurus ke atas. Dengan melihat pola latihan pull over, maka diasumsikan dapat meningkatkan kemampuan pada otot-otot lengan khususnya pada biceps dan triceps.

\section{METODE}

Variabel merupakan obyek penelitian atau sesuatu yang hendak diselidiki sebagai titik pusat perhatian suatu penelitian. Dalam penelitian ini pada dasarnya ada dua variabel yaitu (1) Variabel bebas yaitu: latihan pull over dan kelompok control; dan (2) Variabel terikat yaitu kemampuan smash bulutangkis. Metode yang digunakan pada penelitian adalah metode eksperimen dengan desain Randomized Control Group Pre tes - Post test. Populasi dari penelitian ini adalah semua mahasiswa FIK UNM yang telah lulus mata kuliah bulutangkis, sedangkan sampel yang digunakan dalam penelitian ini adalah sebanyak 20 orang mahasiswa FIK UNM yang diporoleh dengan teknik Simple Random Sampling dengan cara undian. Teknik analisis data yang digunakan adalah yakni uji t. data baku berupa hasil test kemampuan pukulan smash dalam permainan bulu tangkis yang harus di cari ratio dari efek yang berhubungan yang masing-masing hipotesis.

\section{HASIL DAN PEMBAHASAN Hasil Tes Awal Smash Bulutangkis}

Berdasarkan rangkuman hasil analisis deskripsi data tes awal kemampuan smash pada permainan bulutangkis, yang terdiri dari kelompok latihan pull over dan kelompok kontrol, dapat dikemukakan sebagai berikut:

Tabel 1.

Hasil analisis deskripsi data tes awal kemampuan smash bulutangkis.

\begin{tabular}{|l|c|c|c|c|c|c|c|}
\hline \multicolumn{1}{|c|}{ Nilai statistik } & $\mathrm{N}$ & Mean & SD & Range & Min & Max & Sum \\
\hline Latihan pull over & 10 & 11,10 & 3,479 & 9 & 6 & 15 & 111 \\
\hline Klp control & 10 & 10,20 & 3,521 & 9 & 6 & 15 & 102 \\
\hline
\end{tabular}

Dari tabel diatas merupakan gambaran data tes awal kemampuan smash pada permainan bulutangkis, dapat dikemukakan sebagai berikut:
1. Kelompok latihan pull over, dalam melakukan tes kemampuan smash pada permainan bulutangkis, diperoleh nilai rata-rata 11,10 point dari 10 sampel, dengan jumlah nilai secara keseluruhan 


\section{e-ISSN: 2657-0703 dan p-ISSN: 2085-5389}

sebanyak 111 point. Untuk nilai standar deviasi 3,479 dengan range 9 point dari nilai minimal 6 point dan nilai maksimal 15 point.

2. Kelompok kontrol, dalam melakukan tes kemampuan smash pada permainan bulutangkis, diperoleh nilai rata-rata 10,20 point dari 10 sampel dengan jumlah nilai secara keseluruhan sebanyak 102 point. Untuk nilai standar deviasi 3,521 dengan range 9 point dari nilai minimal 6 point dan nilai maksimal 15 point.

\section{Hasil Data Tes Akhir Smash Bulutangkis}

Berdasarkan rangkuman hasil analisis deskripsi data tes akhir kemampuan smash pada permainan bulutangkis, yang terdiri dari kelompok latihan pull over dan kelompok kontrol, dapat dikemukakan sebagai berikut:

Tabel 2.

Hasil analisis deskripsi data tes akhir smash bulutangkis

\begin{tabular}{|l|c|c|c|c|c|c|c|}
\hline \multicolumn{1}{|c|}{ Nilai statistik } & $\mathrm{N}$ & Mean & SD & Range & Min & Max & Sum \\
\hline Latihan pull over & 10 & 14,40 & 3,098 & 9 & 9 & 18 & 144 \\
\hline Klp kontrol & 10 & 12,60 & 3,098 & 9 & 9 & 18 & 126 \\
\hline
\end{tabular}

Dari tabel diatas merupakan gambaran data tes akhir kemampuan smash pada permainan bulutangkis, dapat dikemukakan sebagai berikut:

1. Kelompok latihan pull over, dalam melakukan tes kemampuan smash pada permainan bulutangkis, diperoleh nilai rata-rata 14,40 point dari 10 sampel, dengan jumlah nilai secara keseluruhan sebanyak 144 point. Untuk nilai standar deviasi 3,098 dengan range 9 point dari nilai minimal 9 point dan nilai maksimal 18 point.

2. Kelompok kontrol, dalam melakukan tes kemampuan smash pada permainan bulutangkis, diperoleh nilai rata-rata 12,60 point dari 10 sampel, dengan jumlah nilai secara keseluruhan sebanyak 126 point. Untuk nilai standar deviasi 3,098 dengan range 9 point dari nilai minimal 9 point dan nilai maksimal 18 point.

\section{Hasil Analisis Statistik Inferensial}

Hasil yang dicapai pada kedua uji persyaratan sebelumnya adalah berdistribusi normal, jadi pengujian hipotesis bisa diberlakukan.

\section{Hipotesis Pertama}

Ada pengaruh latihan pull over terhadap kemampuan smash pada permainan bulutangkis.

Hipotesis statistis:

Ho : $\mu \mathrm{A} 1-\mu \mathrm{A} 2=0$

$\mathrm{HI}: \mu \mathrm{A} 1-\mu \mathrm{A} 2 \neq 0$

Hasil analisis pada lampiran penelitian dapat dirangkum dalam Tabel berikut:

Tabel 3.

Hasil analisis hipotesis pertama

\begin{tabular}{|c|c|c|}
\hline thitung & ttabel & Keterangan \\
\hline$-11,000$ & 1,833 & Signifikan \\
\hline
\end{tabular}

Kesimpulan:

Dari hasil rangkuman tabel 3 , maka nilai thitung $=-11,000<$ dari ttabel $=1,833$ pada taraf signifikan $95 \%$ atau 0,05 . Jadi Ho ditolak dan HI diterima, berarti ada perbedaan tes awal dan tes akhir. Maka ada pengaruh latihan pull over terhadap kemampuan smash pada permainan bulutangkis. karena nilai t hitung negatif, berarti rata-rata kemampuan smash, sebelum melakukan latihan pull over rendah daripada sesudah latihan pull over.

\section{Hipotesis Kedua}

Ada pengaruh kelompok kontrol terhadap kemampuan smash pada permainan 


\section{Volume 10 Nomor 2 Juni 2018}

bulutangkis.

Hipotesis statistis:

Ho $: \mu \mathrm{B} 1-\mu \mathrm{B} 2=0$

$\mathrm{HI}: \mu \mathrm{B} 1-\mu \mathrm{B} 2 \neq 0$
Hasil analisis pada lampiran penelitian dapat dirangkum dalam Tabel berikut:

Tabel 4.

Hasil analisis hipotesis kedua

\begin{tabular}{|c|c|c|}
\hline thitung & ttabel & Keterangan \\
\hline$-6,000$ & 1,833 & Signifikan \\
\hline
\end{tabular}

Kesimpulan:

Dari hasil rangkuman tabel 4 , maka nilai $\mathrm{t}$ hitung $=-6,000<$ dari ttabel $=1,833$ pada taraf signifikan $95 \%$ atau 0,05 . Jadi Ho ditolak dan HI diterima, berarti ada perbedaan tes awal dan tes akhir. Maka ada pengaruh kelompok kontrol yang tidak signifikan terhadap kemampuan smash pada permainan bulutangkis. Karena nilai $\mathrm{t}$ hitung negatif, berarti rata-rata kemampuan smash, tes awal pada kelompok kontrol rendah daripada tes akhir pada kelompok kontrol, nilai rata-rata tersebut tidak berbeda secara signifikan antara tes awal dan tes akhir kemampuan smash pada permainan bulutangkis

\section{Hipotesis Ketiga}

Ada perbedaan pengaruh antara latihan pull over dan kelompok kontrol terhadap kemampuan smash pada permainan bulutangkis.

Hipotesis statistis:

Ho $: \mu \mathrm{A} 2-\mu \mathrm{B} 2=0$

$\mathrm{HI}: \mu \mathrm{A} 2-\mu \mathrm{B} 2 \neq 0$

Hasil analisis pada lampiran penelitian dapat dirangkum dalam Tabel berikut:

Tabel 5.

Hasil analisis hipotesis ketiga

\begin{tabular}{|l|l|l|}
\hline thitung & tabel & Keterangan \\
\hline 3,674 & 1,833 & Berpengaruh \\
\hline
\end{tabular}

Kesimpulan:

Dari hasil rangkuman tabel 5 , maka nilai $\mathrm{t}$ hitung $=3,674>$ dari ttabel $=1,833$ dan $P$ value $(0,546>0,05)$ maka H0 diterima, berarti ada perbedaan antara kedua kelompok tersebut. Maka ada perbedaan pengaruh antara kelompok latihan pull over yang lebih besar daripada kelompok kontrol terhadap kemampuan smash pada permainan bulutangkis, karena nilai $t$ hitung negatif, berarti rata-rata kemampuan smash pada kelompok latihan pull over rendah daripada kelompok kontrol.

\section{Pembahasan}

Untuk memperjelas hasil penelitian yang telah dianalisis melalui pengolahan data statistik, maka pada bagian ini akan diuraikan tentang pembahasan hasil penelitian.

\section{Keadaan kelompok sebelum melakukan latihan}

Berdasarkan hasil pengujian normalitas sampel diperoleh hasil probabilitas yang lebih besar dari tabel pada taraf signifikan $95 \%$ atau 0,05 . hasil ini menunjukkan bahwa sampel yang dikelompokkan, sebelum melakukan latihan memiliki kemampuaan yang sama atau dengan kata lain homogen. Dengan kemampuan yang sama atau hampir sama, apabila setelah latihan yang berbeda dan waktu yang sama pada kelompok latihan akan berakhir dengan kemampuan yang berbeda dengan kelompok kontrol, maka perbedaan itu disebabkan oleh pengaruh latihan yang telah 
dilakukan. Harsono (1988:102) bahwa: "Dengan berlatih secara sistematis dan melalui pengulangan - pengulangan yang konstan, maka organisasi-organisasi mekanisme neurophysiologis kita akan menjadi bertambah baik". Seperti yang telah diterapkan pada latihan pull over.

\section{Keadaan kelompok latihan dan kelompok kontrol}

a. Kelompok latihan pull over

Pada kelompok yang diberikan latihan pull over, hasil analisis data menunjukkan adanya perbedaan antara hasil tes awal dan hasil tes akhir kemampuan smash pada permainan bulutangkis. Perbedaan tersebut dapat dikatakan bahwa ada pengaruh latihan pull over terhadap kemampuan smash pada permainan bulutangkis. Latihan pull over yang diterapkan adalah untuk mengembangkan unsur power (daya ledak) pada lengan dan bahu sehingga diharapkan setelah pemberian latihan pull over, kekuatan dapat dikembangkan dari kemampuan sebelumnya. Berdasarkan pelaksanaan latihan pull over, maka dapat diinterpretasikan adanya pengaruh secara kausal dari latihan tersebut, bahwa dengan waktu yang singkat dapat merangsang gerakan dan mempengaruhi kekuatan lengan dan bahu pada saat melakukan smash pada permainan bulutangkis. Dengan demikian, gerakan yang dilakukan dalam latihan pull over adalah meningkatkan otot dada, latisimus dorsi, teres mayor pastoralis, rhomboids, triceps, coracobracialos, biceps. Unsur-unsur fisik dan bagian-bagian struktur tubuh tersebut sebagai penunjang dalam melakukan gerakangerakan olahraga, sehingga terjadi peningkatan kemampuan smash pada permainan bulutangkis. Oleh sebab itu, latihan pull over yang melaksanakan unsur gerak, secara tidak langsung meningkatkan kemampuan smash bulutangkis. Harsono (1988) bahwa: "Latihan adalah proses sistematis dari berlatih atau bekerja yang dilakukan secara berulang-ulang yang kian hari kian bertambah jumlah beban latihannya atau pekerjaanya".

\section{b. Kelompok kontrol}

Untuk kelompok kontrol yang tidak diberikan latihan, hasil analisis data menunjukkan adanya perbedaan antara hasil tes awal dan hasil tes akhir kemampuan smash pada permainan bulutangkis, seperti yang terjadi pada kelompok latihan pull over. Dengan demikian, dapat dikatakan bahwa perbedaan tersebut disebabkan oleh pengaruh pre-test (tes awal) kemampuan smash pada permainan bulutangkis, sehingga perbedaan tersebut tidak menunjukkan yang signifikan. Dalam hal ini, adanya perbedaan antara tes awal dan tes akhir, disebabkan oleh pengalaman bermakna dalam melakukan kemampuan smash pada permainan bulutangkis. Selain itu, kelompok kontrol tidak dikarantinakan sehingga memungkinkan melakukan gerakan yang menyerupai pada kelompok latihan pull over, kendati tidak secara terprogram.

\section{Keadaan perbedaan pengaruh}

Kedua kelompok yang telah diuraikan di atas, mengungkapkan bahwa kelompok latihan pull over memberikan pengaruh kemampuan smash pada permainan bulutangkis yang lebih besar, dari pada kemampuan smash, yang dilakukan oleh kelompok kontrol. Kelompok latihan pull over lebih besar peningkatannya, karena bentuk geraknya telah menyerupai gerakan smash, sehingga lebih mudah dalam mempengaruhi fleksibilitas dan rangsangan menambah kekuatan pada bagian lengan, dibandingkan dengan kelompok kontrol yang tidak diberikan perlakuan langsung dalam penelitian ini. Uraian perbedaan pengaruh latihan pada kedua kelompok, terhadap kemampuan smash pada permainan bulutangkis, pada dasarnya dapat melakukan kemampuan smash, tetapi menghasilkan gerakan pukulan smash dan hasil yang berbeda pula. Seperti yang dikemukakan oleh Zaichkowsky (dalam Lutan, 1988:349) bahwa empat alasan utama terjadinya perbedaan dalam penampilan gerak, termasuk kemampuan smash, sebagai bagian dari keterampilan, yaitu: "(1) bentuk tubuh, (2) struktur anatomis, (3) fungsi fisiologis, dan (4) faktor-faktor budaya." Dengan demikian, bahwa bentuk-bentuk latihan, termasuk latihan pull over sebagai pengembangan fungsi anatomis dalam melakukan gerak-gerakan olahraga. Serta kelompok kontrol melakukan gerakan diluar dari kontrol peneliti. Secara umum mempengaruhi kemampuan smash pada permainan bulutangkis, seperti yang 
diuraikan pada kajian teori.

\section{SIMPULAN DAN SARAN}

Berdasarkan hasil penelitian dan pembahasan pada bagian terdahulu dapat disimpulkan sebagai berikut: (1) Ada pengaruh latihan pull over terhadap kemampuan smash pada permainan bulutangkis, (2) Ada pengaruh kelompok kontrol yang tidak signifikan terhadap kemampuan smash pada permainan bulutangkis, dan (3) Ada perbedaan pengaruh antara latihan pull over yang lebih baik daripada kelompok kontrol terhadap kemampuan smash pada permainan bulutangkis.

Berdasarkan kesimpulan yang telah diuraikan di atas, maka disarankan beberapa hal yaitu: (1) Peningkatan kemampuan smash pada permainan bulutangkis dapat dilakukan melalui latihan pull over, (2) Diharapkan setiap klub dapat memprogramkan latihan pull over yang lebih efektif, untuk peningkatan kemampuan smash pada permainan bulutangkis, dan (3) Dengan meningkatnya kemampuan smash pada permainan bulutangkis, maka kualitas gerak akan semakin baik, sehingga diharapkan kepada pelatih dan lembaga keolahragaan untuk memperhatikan bentuk-bentuk latihan yang dilakukan.

\section{DAFTAR RUJUKAN}

Bompa, To. 1983. Theory and Methodology of Training. The Key to Athletic Performance, IOWA: Kendhal/Hant, Publishing Compani.

Edward. L. Fox.1984. Sport Physiologi, Philadelphia, Sounders College Publishing.

Harsono, 1988. Coaching dan Aspek-Aspek Dalam Coaching. Depdikbud Dirjen Dikti.

Johnso, M. L.1982. Bimbingan Permainan Bulutangkis. Penerbit Mutiara Jakarta.

Kosasih, Engkos. 1985. Olahraga Teknik dan Program Latihan, CV. Akademia Presindo, Jakarta.

Nossek. 1994. General Theory of Training. Pan Africa Press, LTD. Lagos.

PB. PBSI. 1985. Pola Pembinaan Bulutangkis Nasional.

Diterbitkan Oleh PB. PBSI. J akarta.

PB. PBSI. 2002. Pedoman Praktis Bermain Bulutangkis.

Diterbitkan Oleh PB. PBSI. Jakarta.
Sajoto. 1988. Permainan Londisi Fisik Dalam OLahraga. FPOK IKIP Semarang. Semarang.

Singer, N. Robert. 1989. Motor Learning and performance Application to Motor Skill and Movement Behavior. New Mc. Milian Publishing Co Inc.

Siregar, M. F. 1974. Ilmu Pengetahuan Melatih. Jakarta: Proyek Pembinaan Prestasi Olahraga.

Tohar, M. 1992. Olahraga Pilihan Bulutangkis. Jakarta: Depdikbud Dirjen Dikti. 